\title{
Considerations for payers in managing hormone receptor-positive advanced breast cancer
}

This article was published in the following Dove Press journal:

ClinicoEconomics and Outcomes Research

10 July 2014

Number of times this article has been viewed

\author{
Mona Chitre' \\ Kristen M Reimers ${ }^{2}$ \\ 'Pharmacy Management, Excellus \\ BlueCross BlueShield, Rochester, \\ NY, USA; ${ }^{2}$ Clinical Drug Programs, \\ Magellan Health/Icore, Orlando, \\ FL, USA
}

\begin{abstract}
Breast cancer (BC) is the second most common cause of death in women. In 2010, the direct cost associated with $\mathrm{BC}$ care in the US was $\$ 16.5$ billion, the highest among all cancers. By the year 2020, at the current rates of incidence and survival, the cost is projected to increase to approximately $\$ 20$ billion. Although endocrine therapies to manage hormone receptor-positive $(\mathrm{HR}+) \mathrm{BC}$ are highly effective, endocrine resistance results in disease progression. Increased understanding of endocrine resistance and the mechanisms of disease progression has led to development and subsequent approval of novel targeted treatments, resulting in the expansion of the therapeutic armamentarium to combat $\mathrm{HR}+\mathrm{BC}$. Clear guidelines based on the safety and efficacy of treatment options exist; however, the optimal sequence of therapy is unknown, and providers, payers, and other key players in the health care system are tasked with identifying cost-effective and evidence-based treatment strategies that will improve patient outcomes and, in time, help curb the staggering increase in cost associated with BC care. Safety and efficacy are key considerations, but there is also a need to consider the impact of a given therapy on patient quality of life, treatment adherence, and productivity. To minimize cost associated with overall management, cost-effectiveness, and financial burden that the therapy can impose on patients, caregivers and managed care plans are also important considerations. To help evaluate and identify the optimal choice of therapy for patients with $\mathrm{HR}+$ advanced BC, the available data on endocrine therapies and novel agents are discussed, specifically with respect to the safety, efficacy, financial impact on patients and the managed care plan, impact on quality of life and productivity of patients, and improvement in patient medication adherence.
\end{abstract}

Keywords: everolimus, quality of life, mTOR inhibitor, endocrine therapy, managed care

\section{Introduction}

In 2010, the most recent year for which data are available, almost 1.6 million cases of breast cancer (BC) of all types were reported around the world. ${ }^{1}$ In the United States, $\mathrm{BC}$ accounts for nearly one in three cancers diagnosed in women, ${ }^{2}$ and more than 232,670 new BC cases are estimated to be diagnosed in the United States in $2014 .{ }^{3} \mathrm{BC}$ is the second most common cause of death because of cancer (Figure 1) in US women; almost 40,000 deaths from the disease are estimated in 2014. ${ }^{3}$ Metastatic BC is largely incurable, ${ }^{4}$ and the 5 -year relative survival rate is just $23.3 \%$ compared with $98.6 \%$ for localized disease. ${ }^{5}$ Women 40 years of age and older account for $95 \%$ of new BC cases in the US and for $97 \%$ of deaths. ${ }^{2}$ A recent National Cancer Institute report shows that in 2010 the direct cost in the US associated with BC care was \$16.5 billion (Figure 2), the highest among all cancers, and with the current incidence and survival rates, the cost is projected to increase to approximately $\$ 20$ billion by the year 2020 . $^{6}$
Correspondence: Kristen M Reimers Clinical Drug Programs, Magellan Health/lcore, 6870 Shadowridge Drive, Orlando, FL 328I2, USA

Tel +l 8605070938 ext 70938

Email kmreimers@magellanhealth.com 


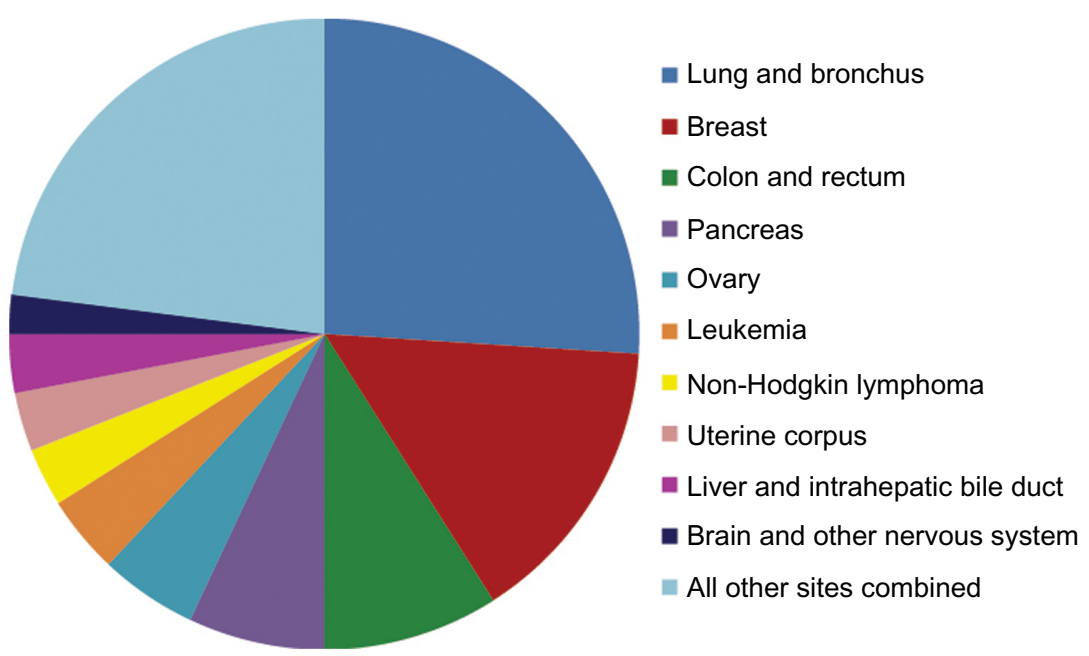

Figure I Estimated cancer-related death in women.

Note: Reproduced with permission from the American Cancer Society Cancer Facts and Figures 2014. Atlanta: American Cancer Society, Inc. ${ }^{3}$

Approximately $75 \%$ of patients diagnosed with advanced $\mathrm{BC}(\mathrm{ABC})$ have hormone receptor-positive (HR+) disease, ${ }^{7,8}$ which has the most favorable prognosis. ${ }^{2,9}$ In these patients, the NCCN Clinical Practice Guidelines In Oncology (NCCN Guidelines ${ }^{\circledR}$ ) recommend the use of endocrine therapy (eg, tamoxifen or aromatase inhibitors [AIs]) with or without chemotherapy (eg, anthracyclines, taxanes, antimetabolites, or microtubule inhibitors). ${ }^{10}$ A number of targeted therapies, such as bevacizumab, trastuzumab, or everolimus, may be considered in selected patients (ie, trastuzumab for patients with human epidermal growth factor receptor 2-positive disease).${ }^{10}$ Although treatment guidelines, such as those from the National Comprehensive Cancer Network ${ }^{\circledR}\left(\mathrm{NCCN}^{\circledR}\right),{ }^{10}$ provide recommendations for treating patients with $\mathrm{HR}+$ $\mathrm{BC}$ based on clinical trial evidence of safety and efficacy, the guidelines rarely compare different treatment options or provide guidance on how to minimize treatment cost while maximizing benefits. Additionally, guidelines ${ }^{10}$ often do not provide adequate direction regarding therapeutic options when the preferred therapeutic agent is contraindicated in a patient. Therefore, payers have an expanding and obligatory role to ensure that the plan-approved optimal endocrine therapy and subsequent treatment options provided for individual patients with $\mathrm{HR}+\mathrm{ABC}$ are evidence based.

This review provides an overview of some of the major payer issues that should be considered in the management of $\mathrm{HR}+\mathrm{ABC}$. Considerations for health care stakeholders, including payers, are explored with respect to the safety and efficacy of approved therapies in patients with $\mathrm{HR}+\mathrm{ABC}$, the cost and financial impact of the therapy on patients and the managed

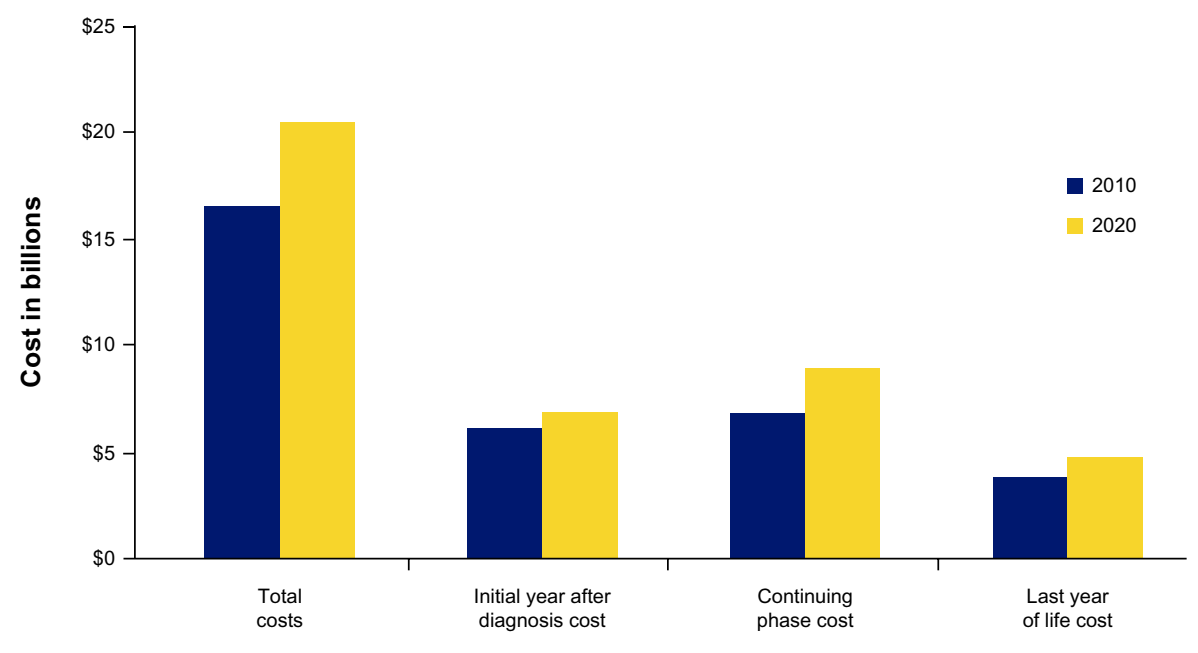

Figure 2 Cost associated with breast cancer.

Note: Data from Mariotto AB, Yabroff KR, Shao Y, Feuer EJ, Brown ML. Projections of the Cost of Cancer Care in the U.S.: 20I0-2020. J Natl Cancer Inst. 20II Jan. ${ }^{6}$ 
care plan, the impact of the therapy on quality of life (QOL) and productivity of patients, and any effect that the therapy may have on improving patient medication adherence. Relevant articles were identified by a search of the PubMed database for articles on the safety, efficacy, QOL, and cost of current treatment options in the management of $\mathrm{HR}+\mathrm{ABC}$.

\section{Considerations for payers Efficacy considerations}

For postmenopausal patients with $\mathrm{HR}+\mathrm{ABC}$, there is a wealth of clinical data supporting the use of third-generation AIs (Table 1), ${ }^{11-17}$ which are recommended as both first- and second-line treatment options. ${ }^{4,9,10,18,19}$ Indeed, numerous randomized controlled trials have shown the efficacy of third-generation AIs (anastrozole, letrozole, or exemestane) with regard to response rate, disease- or recurrence-free survival, time to tumor progression, and for letrozole, overall survival; ${ }^{11-13}$ based on the available efficacy data, the three available AIs are potentially interchangeable. Although AIs are preferred, tamoxifen, a selective estrogen receptor modulator (SERM), is an acceptable first-line therapy, ${ }^{4,10}$ potentially because of extensive clinical data (Table 1). In the adjuvant setting, continuation of tamoxifen for 10 years significantly lowered the risk for $\mathrm{BC}$ recurrence and death compared with discontinuation of treatment after 5 years. ${ }^{20}$ No differences were found in terms of overall survival between tamoxifen and third-generation AIs. ${ }^{21,22}$ Because the available endocrine therapies are all clinically effective in treating patients with $\mathrm{HR}+\mathrm{ABC}$, there is a clear need to carefully weigh the net clinical benefit associated with these therapies.

Table I Approved endocrine and targeted treatments for ABC

\begin{tabular}{|c|c|c|c|c|c|}
\hline Therapy & US FDA approval for $A_{B C}$ & $\begin{array}{l}\text { Route of } \\
\text { administration } \\
\text { and dose for } B C\end{array}$ & Efficacy in BC trials & Common AEs & $\begin{array}{l}\text { AWP per } \\
\text { 30-day } \\
\text { supply }\end{array}$ \\
\hline \multicolumn{6}{|l|}{ Als } \\
\hline Anastrozole ${ }^{\prime \prime}$ & $\begin{array}{l}\text { ABC treatment after } \\
\text { progression on tamoxifen; } \\
\text { first-line treatment of } \\
\text { postmenopausal women } \\
\text { with } \mathrm{HR}+\mathrm{ABC}\end{array}$ & Oral, I mg daily & $\begin{array}{l}\text { First-line: TTP (8.2-I I.I mos); } \\
\text { ORR ( } 2 \text { I.I\%-32.9\%) } \\
\text { Posttamoxifen: TTP (4.4-5.7 mos); } \\
\text { ORR (I0.0\%-I5.3\%) }\end{array}$ & $\begin{array}{l}\text { Arthralgia, } \\
\text { arthritis, fractures, } \\
\text { hot flashes }\end{array}$ & $\$ 405$ \\
\hline Letrozole $^{12}$ & $\begin{array}{l}\text { Second-line treatment } \\
\text { of } \mathrm{HR}+\mathrm{ABC} \text { after previous } \\
\text { antiestrogen; first-line } \\
\text { treatment of postmenopausal } \\
\text { women with } \mathrm{HR}+\mathrm{ABC}\end{array}$ & Oral, 2.5 mg daily & $\begin{array}{l}\text { First-line: OS ( } 35 \text { mos); } \\
\text { TTP ( } 9.4 \text { mos); ORR ( } 32 \%) \\
\text { After antiestrogen: OS } \\
\text { ( } 2 \text { I.I-2I.2 mos); TTP (3.4-5.I mos); } \\
\text { ORR (II.7\%-I } 7.6 \%)\end{array}$ & $\begin{array}{l}\text { Arthralgia, } \\
\text { arthritis, fractures, } \\
\text { hot flashes }\end{array}$ & $\$ 543.90$ \\
\hline Exemestane $^{13}$ & $\begin{array}{l}\text { Treatment of postmenopausal } \\
\text { women whose disease } \\
\text { progressed after tamoxifen }\end{array}$ & Oral, 25 mg daily & $\begin{array}{l}\text { After tamoxifen: TTP (4.7 mos); } \\
\text { ORR (I5.0\%) }\end{array}$ & $\begin{array}{l}\text { Fatigue, nausea, } \\
\text { hot flashes, pain }\end{array}$ & $\$ 397.20$ \\
\hline \multicolumn{6}{|l|}{ SERDs } \\
\hline Fulvestrant $^{14}$ & $\begin{array}{l}\text { At a dose of } 250 \mathrm{mg} \text { or } \\
500 \mathrm{mg} \text { for HR+ BC with } \\
\text { disease progression after } \\
\text { antiestrogen therapy }\end{array}$ & $\begin{array}{l}\text { IM, } 500 \text { mg on } \\
\text { days I, I5, } 29 \text {, } \\
\text { and monthly } \\
\text { thereafter }\end{array}$ & $\begin{array}{l}\text { After antiestrogen: OS ( } 22.8 \mathrm{mos} \\
\text { for } 250 \mathrm{mg} ; 25.1 \mathrm{mos} \text { for } 500 \mathrm{mg}) \text {; } \\
\text { PFS ( } 5.4 \mathrm{mos} \text { for } 250 \mathrm{mg} ; 6.5 \mathrm{mos} \\
\text { for } 500 \mathrm{mg}) \text {; ORR (1 } 4.6 \% \text { for } \\
250 \mathrm{mg} ; \mathrm{I} 3.8 \% \text { for } 500 \mathrm{mg})\end{array}$ & $\begin{array}{l}\text { Nausea, asthenia, } \\
\text { pain, pharyngitis, } \\
\text { hot flashes }\end{array}$ & $\begin{array}{l}\text { First month } \\
\$ 6,318 \text {; every } \\
\text { month after } \\
\$ 2,106\end{array}$ \\
\hline \multicolumn{6}{|l|}{ SERMs } \\
\hline Tamoxifen ${ }^{11,12,15}$ & Treatment of metastatic $B C$ & Oral, 20 mg daily & $\begin{array}{l}\text { First-line: OS (32 mos); } \\
\text { TTP (5.6-8.3 mos); } \\
\text { ORR (I7.0\%-32.6\%) }\end{array}$ & $\begin{array}{l}\text { Hot flashes, edema, } \\
\text { amenorrhea, } \\
\text { vaginal discharge, } \\
\text { endometrial cancer, } \\
\text { thrombotic events }\end{array}$ & $\$ 113.70$ \\
\hline \multicolumn{6}{|c|}{ mTOR inhibitor } \\
\hline Everolimus $^{16}$ & $\begin{array}{l}\text { For use in combination with } \\
\text { exemestane to treat certain } \\
\text { postmenopausal women } \\
\text { with HR+, HER2- ABC }\end{array}$ & Oral, 10 mg daily & $\begin{array}{l}\text { After NSAI: PFS (7.8 mos); } \\
\text { ORR (I } 2.6 \%)^{\mathrm{b}}\end{array}$ & $\begin{array}{l}\text { Stomatitis, rash, } \\
\text { diarrhea, fatigue, } \\
\text { infection }\end{array}$ & $\$ 9,424.24$ \\
\hline
\end{tabular}

Notes: aAgents approved for managing only $A B C$ are shown; bplus Al.

Abbreviations: ABC, advanced breast cancer; AE, adverse event; Al, aromatase inhibitor; AWP, average wholesale price; BC, breast cancer; US FDA, US Food and Drug Administration; HER2-, human epidermal growth factor receptor 2-negative; HR+, hormone receptor positive; IM, intramuscular; mos, months; mTOR, mammalian target of rapamycin; NSAI, nonsteroidal aromatase inhibitor; ORR, objective response rate; OS, overall survival; PFS, progression-free survival; SERD, selective estrogen receptor downregulator; SERM, selective estrogen receptor modulator; TTP, time to progression. 


\section{Endocrine resistance}

Approximately $25 \%$ of patients with $\mathrm{HR}+$ disease have intrinsic endocrine resistance, while responders to initial endocrine therapy will ultimately have disease progression as a result of acquired resistance. ${ }^{23-25}$ No definitive guideline recommendation exists for the order of sequencing of endocrine treatments; however, evidence suggests that response to one endocrine therapy predicts the likelihood of a subsequent response to another endocrine agent, although duration of response is not predictable. ${ }^{26}$ A clear understanding of the different mechanisms of endocrine resistance has led to the identification of a number of novel therapies that are either in clinical or early stage trials. Fulvestrant (Table 1), ${ }^{1-17}$ a selective estrogen receptor downregulator, is an estrogen receptor antagonist ${ }^{14,27}$ indicated for management of $\mathrm{HR}+$ ABC in postmenopausal women after unsuccessful antiestrogen therapy. ${ }^{14,28,29}$ Based on the finding that everolimus (Table 1), ${ }^{11-17}$ an inhibitor of the mammalian target of rapamycin (mTOR), in combination with exemestane is effective in BC patients with endocrine resistance, ${ }^{30,31}$ the US Food and Drug Administration recently approved this combination for treating patients with $\mathrm{HR}+\mathrm{ABC}$ refractory to prior nonsteroidal AI therapy. ${ }^{32}$ In patients with endocrineresistant metastatic $\mathrm{BC}$, chemotherapy might be considered (Table 2). ${ }^{10,33}$ Despite numerous clinical trials, little evidence suggests significant differences in survival outcomes among chemotherapeutic agents..$^{33,34}$

\section{Safety considerations}

The various $\mathrm{BC}$ treatments are associated with a range of adverse events (AEs). Most patients have cancer-related fatigue, which may be exacerbated by treatment. ${ }^{35}$ Bone loss and arthralgia are associated with AI treatment and, depending on severity, may threaten the daily activities of patients. ${ }^{36,37}$ Women with a first-time diagnosis of BC had a fivefold higher risk for vertebral fracture in the subsequent 3-year period than did individuals with no $\mathrm{BC}$, and the risk is more than 20-fold higher in women with recurrent BC. ${ }^{38}$ Even though SERMs help preserve the bone, ${ }^{39}$ they are associated with increased risk for thromboembolism, vaginal bleeding, ocular changes, and endometrial carcinoma. ${ }^{22,40}$ Although fulvestrant does not increase the risks commonly seen with SERMs and AIs, gastrointestinal disturbances, hot flushes/flashes, and joint disorders have been observed with this agent. ${ }^{41}$ The AEs associated with everolimus include stomatitis, rash, fatigue, and digestive issues (diarrhea, decreased appetite, nausea). ${ }^{16,30}$ Chemotherapy can cause severe toxicity, including peripheral neuropathy, ${ }^{35}$ hand-foot
Table 2 Recommended chemotherapeutic regimens for the treatment of $A B C^{10}$

\begin{tabular}{ll}
\hline Single agents & Combinations \\
\hline $\begin{array}{l}\text { Preferred agents } \\
\text { - Anthracyclines: doxorubicin, }\end{array}$ & CAF: cyclophosphamide/ \\
pegylated liposomal doxorubicin & doxorubicin/fluorouracil \\
- Taxanes: paclitaxel & FAC: fluorouracil/doxorubicin/ \\
- Antimetabolites: capecitabine, & cyclophosphamide \\
gemcitabine & FEC: fluorouracil/epirubicin/ \\
- Microtubule inhibitors: & cyclophosphamide \\
vinorelbine, eribulin & AC: doxorubicin/cyclophosphamide \\
Other options & EC: epirubicin/cyclophosphamide \\
- Cyclophosphamide & GemCarbo: gemcitabine/carboplatin \\
- Cisplatin & CMF: cyclophosphamide/ \\
- Carboplatin & methotrexate/fluorouracil \\
- Ixabepilone & Docetaxel/capecitabine \\
- Docetaxel & GT: gemcitabine/paclitaxel \\
- Albumin-bound paclitaxel & Paclitaxel + bevacizumab \\
- Epirubicin & \\
\hline
\end{tabular}

Notes: ${ }^{2}$ Not currently FDA approved. Adapted with permission from the NCCN Clinical Practice Guidelines in Oncology (NCCN Guidelines ${ }^{\circledR}$ ) for Breast Cancer V.3.2014. (c) 2014 National Comprehensive Cancer Network, Inc. All rights reserved. The NCCN Guidelines ${ }^{\circledR}$ and illustrations herein may not be reproduced in any form for any purpose without the express written permission of the NCCN. To view the most recent and complete version of the NCCN Guidelines, go online to NCCN.org. NATIONAL COMPREHENSIVE CANCER NETWORK ${ }^{\circledR}$, NCCN ${ }^{\circledR}$, NCCN GUIDELINES ${ }^{\circledR}$, and all other NCCN Content are trademarks owned by the National Comprehensive Cancer Network, Inc. ${ }^{10}$

Abbreviations: $A B C$, advanced breast cancer; FDA, US Food and Drug Administration; NCCN, National Comprehensive Cancer Network.

syndrome, ${ }^{42}$ severe febrile neutropenia, cardiotoxicity, ${ }^{43}$ and bone marrow suppression.

\section{Quality-of-life considerations}

Approximately 3.8 million $\mathrm{BC}$ survivors are estimated to be alive in 2022, largely because of significant improvements in diagnosis and treatment-related breakthroughs. ${ }^{44}$ Because the survival rate of women with $\mathrm{BC}$ is increasing, ${ }^{44}$ consideration of QOL of these patients in terms of emotional well-being, physical functioning, psychosocial well-being, socioeconomic concerns, and behavioral outcomes becomes important. Younger women with BC may have particular concerns about infertility and premature menopause, which are not an issue for postmenopausal women with BC. ${ }^{45,46}$ Weight gain and physical inactivity as a result of BC therapy might also be a problem resulting in negative body image, decreased libido, and comorbidity associated with obesity. ${ }^{46}$ Lack of motivation, decreased productivity, and days of missed work are also factors that negatively influence the QOL of patients. ${ }^{47}$ For some women with BC, dealing with adverse reaction management and potential job loss (either through inability to continue or redundancy) is a source of emotional and financial distress, whereas, for others, inability to care for children as a result of severe adverse 
reactions and the stress of juggling family commitments and hospital appointments might have a negative impact on QOL scores. ${ }^{48}$ Caregivers of patients with BC may also develop anxiety and depression, which have been shown to have a negative impact on QOL. ${ }^{49}$ Although data on the relationship between caregiver costs and decreased QOL are limited, factors such as decreased productivity, missed work days, or the cost of treating anxiety and depression in caregivers have the potential to contribute to increases in caregiver cost. The type, frequency, and severity of AEs associated with BC treatment may also significantly influence QOL. ${ }^{50}$ Populationbased studies show that the range of functional limitations in BC survivors is between $18 \%$ and $54 \% .^{51}$ Even though the AE profiles of endocrine therapies vary and could affect the QOL of patients, results from large trials have not reported significant differences in QOL of patients treated with these agents. ${ }^{52}$ Given that the AEs associated with everolimus are distinct from those seen with endocrine therapies, the QOL of patients may be affected by everolimus therapy. However, a recent analysis of the QOL data from the Breast Cancer Trials of Oral Everolimus-2 (BOLERO-2) suggested that everolimus plus exemestane treatment did not have a negative impact on health-related QOL, as assessed by the European Organisation for Research and Treatment of Cancer QOL core questionnaire (EORTC QLQ-C30), despite an increased incidence of major side effects, compared with exemestane alone. ${ }^{53}$ Unlike the mTOR inhibitors and endocrine therapy, chemotherapy can cause severe toxicity; hence, the QOL impact profile of these agents must be carefully considered. ${ }^{34,43}$ To assess the QOL effect of chemotherapy treatments, the EORTC QLQ-C30 and the EORTC BC questionnaire (BR23) include questions for psychometric assessment, in addition to questions related to specific symptoms or AEs (eg, nausea, fatigue/asthenia, decreased appetite/weight, hot flashes) associated with chemotherapy treatments. ${ }^{54,55}$

The economic burden endured by patients during the course of therapy can affect the QOL of patients. ${ }^{47}$ Economic burden in the form of changes in economic lifestyle, reduction in income, depletion of savings, declaration of bankruptcy, the need to borrow money, and sacrificing of family plans has affected the QOL of patients, even during posttreatment survivorship. ${ }^{47}$

\section{Cost considerations}

A study published in 2008, based on claims data collected in 2004 , estimated that annual health care cost is significantly higher $(\geq \$ 12,828$ per annum in 2004 dollars, equivalent to $\sim \$ 15,600$ in 2012 dollars) for a BC patient than that for a woman without BC. ${ }^{56} \mathrm{~A}$ more recent report published in 2012 , using claims data from 2003-2008, shows that the total health care cost per patient within the first year of BC treatment was $\$ 42,401$ (equivalent to $\sim \$ 48,300$ in 2012 dollars). ${ }^{57}$ The high cost of BC management is due to a number of factors. ${ }^{58}$ Hospitalizations incurred the highest rate of expense, with costs for women with $\mathrm{BC}$ 7.4-fold higher than for those without $\mathrm{BC}$; laboratory testing and diagnostics for BC also incurred substantial monthly costs. ${ }^{56}$ Few research results have been published on the indirect cost of $\mathrm{ABC}$, including loss of income due to absenteeism or early retirement and caregiver burden, although these would be expected to be significant and may help to differentiate among cancer management interventions. A recent report estimated that loss of productivity accounted for $21 \%$ of ABC expenditure, totaling $\$ 2.6$ billion in 5 years. ${ }^{58}$ Treatment-related costs have accounted for $44 \%$ of the $\mathrm{ABC}$ management expenditure. ${ }^{58}$ The average wholesale prices of endocrine therapies and mTOR inhibitors currently approved to treat patients with $\mathrm{HR}+\mathrm{ABC}$ varies, with tamoxifen being the least costly (Table 1). ${ }^{11-17}$ Cost and copays associated with therapies are increasingly a cause for concern for patients and their families, and one in ten patients taking oral anticancer medications discontinued therapy because of high cost, whereas one in four patients with a cost sharing $>\$ 500$ abandoned the oral oncolytic prescription. ${ }^{59}$ To minimize the financial burden on patients and to help improve adherence to therapy, understanding whether additional cost is likely because of AEs specific to one drug class or agent rather than another (eg, a requirement for additional cardiac or bone density monitoring, antihypertensive drugs, statins, or anticoagulants) is important. Evidence shows that treatment with bisphosphonates effectively counteracts bone loss induced by AIs; ${ }^{37}$ nevertheless, in patients treated with AIs, cost associated with addition of bisphosphonates and management of bone-related issues must be considered. Cost associated with additional interventions that might be necessary to manage thromboembolism or endometrial cancer, among others, must be considered if SERMs are the endocrine therapy chosen. Similarly, cost associated with management of severe gastrointestinal disturbances and other AEs associated with fulvestrant or cost associated with interventions for managing stomatitis or rash, among others, related to everolimus use must be considered by providers, patients, payers, and all other stakeholders of the health care system. The current review focuses on the management of $\mathrm{BC}$ from a US perspective. In a recent guidance publication by the National Institute for Health and Care Excellence, 
the appraisal committee indicated that everolimus was not considered a cost-effective treatment option for the National Health Service in the UK. ${ }^{60}$ This highlights the challenges that non-US countries may face in the management of $\mathrm{BC}$, which may arise because of variations in a number of factors, including treatment practices, cost structures, and payer health care systems.

\section{Considerations of cost associated} with treatment adherence

To optimally manage $\mathrm{BC}$ and to achieve treatment goals, adherence to therapy is critical in improving long-term clinical outcomes, including disease recurrence and survival. ${ }^{61,62}$ Furthermore, poor medication adherence negatively affects patients and increases the number of subsequent hospitalizations, ${ }^{62}$ thereby increasing the cost associated with treatment of these patients. In a recent retrospective, longitudinal study evaluating adherence to hormone therapy with tamoxifen or AIs by Medicaid beneficiaries with BC, suboptimal adherence was associated with higher medical costs over the 4-year study period. ${ }^{63}$ Use of AIs, although more expensive than tamoxifen (Table 1), ${ }^{11-17}$ have reduced health care resources, including the number of hospitalizations and outpatient visits and the use of chemotherapy. ${ }^{64}$ Cost savings per patient before and after disease progression were significant for anastrozole over tamoxifen $(P<0.01)$, an important consideration when choosing $\mathrm{ABC}$ treatment. ${ }^{64}$ Letrozole was also a cost-effective alternative to tamoxifen in treating patients with ABC. ${ }^{65}$ Fulvestrant has been a cost-effective treatment option when added as a second- or third-line hormonal therapy for ABC. ${ }^{66}$ Fulvestrant as a second-line hormone therapy provided an additional 56 life-years and 41 quality-adjusted life-years (QALYs) per 1000 women, at an additional cost of $\sim \$ 10,400$ (converted from British pounds) per life-year gained and $\sim \$ 12,000$ per QALY. As a third-line option, fulvestrant provided an increase in health benefit of 27 QALYs for the whole cohort, at a mean overall cost reduction of $\sim \$ 689$ per patient. ${ }^{66}$ The economic viability of newer agents such as everolimus for the management of $\mathrm{BC}$ remains to be established, although a recent costeffectiveness analysis of the BOLERO-2 trial indicated that everolimus plus exemestane seemed to be cost-effective in the treatment of metastatic $\mathrm{BC} .{ }^{67} \mathrm{~A}$ recent analysis showed that total budget impact of adding everolimus as first treatment after unsuccessful nonsteroidal AI therapy in HR+ human epidermal growth-factor receptor 2-negative $\mathrm{ABC}$ patients in a hypothetical managed care organization with 1 million members would be $\$ 0.014$ per member per month, whereas it would be $\$ 0.030$ per member per month if added as a second treatment. ${ }^{68}$ Therefore, as multiple treatment options become available for treating patients with $\mathrm{ABC}$, there is a clear need to look for therapies that provide the most value, thereby helping to minimize the financial impact on patients and on managed care plans.

Providers take into account many factors of patient treatment to minimize drug discontinuation, to ensure adherence, and to prevent or delay relapse or disease progression. Patient preference for oral or injectable agents is also considered. ${ }^{4}$ Many of the available endocrine therapies and the newer novel targeted therapies are orally administered (Table 1). ${ }^{11-17} \mathrm{Com}-$ plicated daily dosing schedules or cognitive issues may cause patients to overdose or miss doses. ${ }^{61}$ Conversely, patients who are afraid of needles could have reduced QOL if required to have weekly or monthly injections. In addition, physician visits and follow-up appointments must be convenient for patients to reduce potential treatment gaps. ${ }^{61}$ Patients who do not understand the rationale behind their therapy or who do not believe that a particular agent will benefit them are more likely to discontinue treatment. ${ }^{61,62}$ The lengthy duration of treatment associated with $\mathrm{ABC}$ may also increase nonadherence in patients as they experience side effects or as additional comorbidity develops. ${ }^{61,62,69}$ Clearly, education regarding AEs that might occur and prompt amelioration of symptoms ${ }^{4}$ are critical to ensure that patients adhere to therapies that provide clinical benefit. Therefore, from the perspective of the providers, payers, and other stakeholders in the health care system, ensuring that patients adhere to cancer therapies and other interventions to manage any AE will help improve the overall outcome for the patient and help control the cost associated with cancer management.

\section{Conclusion}

Despite many advances in screening and treatment, $\mathrm{BC}$ is one of the most common causes of cancer-related death, and advanced disease has a particularly poor prognosis. The direct cost of $\$ 16.5$ billion associated with $\mathrm{BC}$ care in 2010 was the highest among all cancers, and this is projected to increase every year. With recent approval of new treatments and combinations to overcome endocrine resistance, the therapeutic tools available to combat $\mathrm{HR}+\mathrm{ABC}$ in patients are expanding. Although guideline recommendations regarding endocrine and novel therapies exist, the optimal treatment sequence is unknown. Hence, it is critical that the providers, payers, and other stakeholders in the health care system have a clear understanding of the differences among therapeutic agents in terms of safety, 
efficacy, potential impact on QOL of patients, and more importantly, cost associated with therapy and with overall management. In addition to the pharmacotherapy-related factors described herein, patient medical history, overall treatment goals (improve survival, stabilize disease, reduce metastases), and patient personal preference (ability to continue to be productive, minimize financial burden, minimize disability caused by AEs, retain health for a family holiday, survive for a birthday or other special event, or reduce pain or other specific symptom) are all important patient-specific factors for all stakeholders in the health care system to consider when assessing optimal treatment strategies. Treatment selection based on the patient and therapy-related factors will help to slow the staggering cost associated with cancer management, while providing patients with quality care of $\mathrm{ABC}$ and cost-effective, evidence-based treatment options.

\section{Acknowledgments}

The authors thank Sally Mitchel, PhD, Matthew Grzywacz, PhD, and ApotheCom (Yardley, PA, USA) for editorial and technical assistance in the development of this manuscript. Novartis Pharmaceuticals, Inc., provided funding for editorial and technical assistance with the development of this manuscript.

\section{Disclosure}

The authors report no conflicts of interest in this work.

\section{References}

1. Forouzanfar MH, Foreman KJ, Delossantos AM, et al. Breast and cervical cancer in 187 countries between 1980 and 2010: a systematic analysis. Lancet. 2011;378(9801):1461-1484.

2. American Cancer Society. Breast Cancer Facts and Figures: 2011-2012. Atlanta, GA: American Cancer Society; 2012. Available from: http://www. cancer.org/acs/groups/content/@epidemiologysurveilance/documents/ document/acspc-030975.pdf. Accessed December 18, 2013.

3. American Cancer Society. Cancer facts and figures 2014. Atlanta, GA, American Cancer Society; 2014. Available from: http://www.cancer.org/ acs/groups/content/@research/documents/webcontent/acspc-042151. pdf. Accessed June 13, 2014.

4. Cardoso F, Senkus-Konefka E, Fallowfield L, Costa A, Castiglione M; ESMO Guidelines Working Group. Locally recurrent or metastatic breast cancer: ESMO Clinical Practice Guidelines for diagnosis, treatment and follow-up. Ann Oncol. 2010;21(Suppl 5):v15-v19.

5. National Cancer Institute [homepage on the Internet]. SEER Statistic Fact Sheet: Breast Cancer; 2013. Available from: http://seer.cancer.gov/ statfacts/html/breast.html. Accessed December 18, 2013.

6. Mariotto AB, Yabroff KR, Shao Y, Feuer EJ, Brown ML. Projections of the Cost of Cancer Care in the U.S.: 2010-2020. J Natl Cancer Inst. 2011;103(2):117-128.

7. Setiawan VW, Monroe KR, Wilkens LR, Kolonel LN, Pike MC, Henderson BE. Breast cancer risk factors defined by estrogen and progesterone receptor status: the multiethnic cohort study. Am J Epidemiol. 2009;169(10):1251-1259.
8. Anderson WF, Chatterjee N, Ershler WB, Brawley OW. Estrogen receptor breast cancer phenotypes in the Surveillance, Epidemiology, and End Results database. Breast Cancer Res Treat. 2002;76(1): $27-36$.

9. Cleator SJ, Ahamed E, Coombes RC, Palmieri C. A 2009 update on the treatment of patients with hormone receptor-positive breast cancer. Clin Breast Cancer. 2009;9(Suppl 1):S6-S17.

10. National Comprehensive Cancer Network. NCCN Clinical Practice Guidelines in Oncology. Breast Cancer. version 3.2014. NCCN Web site. http://www.nccn.org/professionals/physician_gls/pdf/breast.pdf. Accessed June 9, 2014.

11. Arimidex (anastrozole tablets) [prescribing information]. Wilmington, DE: AstraZeneca Pharmaceuticals LP; 2013.

12. Femara (letrozole tablets) $2.5 \mathrm{mg}$ tablets [prescribing information]. East Hanover, NJ: Novartis Pharmaceuticals Corporation; 2011.

13. Aromasin (exemestane tablets, oral) [prescribing information]. New York, NY: Pharmacia and Upjohn Company; 2013.

14. Faslodex (fulvestrant) injection [prescribing information]. Wilmington, DE: AstraZeneca Pharmaceuticals LP; 2012.

15. Nolvadex (tamoxifen citrate tablet) [prescribing information]. Wilmington, DE: AstraZeneca Pharmaceuticals LP; 2007.

16. Afinitor (everolimus) tablets for oral administration [prescribing information]. East Hanover, NJ: Novartis Pharmaceuticals Corporation; 2014.

17. ReimbursementCodes [homepage on the Internet]. Rocky Hill, CT: RJ Health Systems ReimbursementsCodes. Available from: http:// reimbursementcodes.com/. Accessed December 18, 2013.

18. Johnston SR. New strategies in estrogen receptor-positive breast cancer. Clin Cancer Res. 2010;16(7):1979-1987.

19. Harichand-Herdt S, Zelnak A, O'Regan R. Endocrine therapy for the treatment of postmenopausal women with breast cancer. Expert Rev Anticancer Ther. 2009;9(2):187-198.

20. Davies C, Pan H, Godwin J, et al; Adjuvant Tamoxifen: Longer Against Shorter (ATLAS) Collaborative Group. Long-term effects of continuing adjuvant tamoxifen to 10 years versus stopping at 5 years after diagnosis of oestrogen receptor-positive breast cancer: ATLAS, a randomised trial. Lancet. 2013;381(9869):805-816.

21. Riemsma R, Forbes CA, Kessels A, et al. Systematic review of aromatase inhibitors in the first-line treatment for hormone sensitive advanced or metastatic breast cancer. Breast Cancer Res Treat. 2010; 123(1):9-24.

22. Mao C, Yang ZY, He BF, et al. Toremifene versus tamoxifen for advanced breast cancer. Cochrane Database Syst Rev. 2012; 7:CD008926.

23. Musgrove EA, Sutherland RL. Biological determinants of endocrine resistance in breast cancer. Nat Rev Cancer. 2009;9(9):631-643.

24. Dodwell D, Wardley A, Johnston S. Postmenopausal advanced breast cancer: options for therapy after tamoxifen and aromatase inhibitors. Breast. 2006;15(5):584-594.

25. Osborne CK, Schiff R. Mechanisms of endocrine resistance in breast cancer. Annu Rev Med. 2011;62:233-247.

26. Barrios C, Forbes JF, Jonat W, et al. The sequential use of endocrine treatment for advanced breast cancer: where are we? Ann Oncol. 2012;23(6):1378-1386.

27. Oakman C, Moretti E, Santarpia L, Di Leo A. Fulvestrant in the management of postmenopausal women with advanced, endocrine-responsive breast cancer. Future Oncol. 2011;7(2):173-186.

28. Ingle JN, Suman VJ, Rowland KM, et al; North Central Cancer Treatment Group Trial N0032. Fulvestrant in women with advanced breast cancer after progression on prior aromatase inhibitor therapy: North Central Cancer Treatment Group Trial N0032. J Clin Oncol. 2006;24(7):1052-1056.

29. Perey L, Paridaens R, Hawle H, et al. Clinical benefit of fulvestrant in postmenopausal women with advanced breast cancer and primary or acquired resistance to aromatase inhibitors: final results of phase II Swiss Group for Clinical Cancer Research Trial (SAKK 21/00). Ann Oncol. 2007;18(1):64-69. 
30. Baselga J, Campone M, Piccart M, et al. Everolimus in postmenopausal hormone-receptor-positive advanced breast cancer. $N$ Engl J Med. 2012;366(6):520-529.

31. Yardley DA, Noguchi S, Pritchard KI, et al. Everolimus plus exemestane in postmenopausal patients with $\mathrm{HR}(+)$ breast cancer: BOLERO-2 final progression-free survival analysis. Adv Ther. 2013;30(10): $870-884$.

32. US Food and Drug Administration. FDA approves Afinitor for advanced breast cancer [press release]. Silver Spring, MD: US Food and Drug Administration; July 20, 2012. Available from: http://www.fda.gov/ NewsEvents/Newsroom/PressAnnouncements/ucm312965.htm. Accessed December 18, 2013.

33. Wilcken N, Dear R. Chemotherapy in metastatic breast cancer: A summary of all randomised trials reported 2000-2007. Eur J Cancer. 2008;44(15):2218-2225.

34. O'Shaughnessy J. Extending survival with chemotherapy in metastatic breast cancer. Oncologist. 2005;10(Suppl 3):20-29.

35. Binkley JM, Harris SR, Levangie PK, et al. Patient perspectives on breast cancer treatment side effects and the prospective surveillance model for physical rehabilitation for women with breast cancer. Cancer. 2012;118(Suppl 8):2207-2216.

36. Winters-Stone KM, Schwartz AL, Hayes SC, Fabian CJ, Campbell KL. A prospective model of care for breast cancer rehabilitation: bone health and arthralgias. Cancer. 2012;118(Suppl 8):2288-2299.

37. Santen RJ. Clinical review: effect of endocrine therapies on bone in breast cancer patients. J Clin Endocrinol Metab. 2011;96(2):308-319.

38. Kanis JA, McCloskey EV, Powles T, Paterson AH, Ashley S, Spector T. A high incidence of vertebral fracture in women with breast cancer. Br J Cancer. 1999;79(7-8):1179-1181.

39. Lumachi F, Luisetto G, Basso SM, Basso U, Brunello A, Camozzi V. Endocrine therapy of breast cancer. Curr Med Chem. 2011;18(4): 513-522.

40. Amir E, Seruga B, Niraula S, Carlsson L, Ocaña A. Toxicity of adjuvant endocrine therapy in postmenopausal breast cancer patients: a systematic review and meta-analysis. J Natl Cancer Inst. 2011;103(17): 1299-1309.

41. Croxtall JD, McKeage K. Fulvestrant: a review of its use in the management of hormone receptor-positive metastatic breast cancer in postmenopausal women. Drugs. 2011;71(3):363-380.

42. Hoesly FJ, Baker SG, Gunawardane ND, Cotliar JA. Capecitabineinduced hand-foot syndrome complicated by pseudomonal superinfection resulting in bacterial sepsis and death: case report and review of the literature. Arch Dermatol. 2011;147(12):1418-1423.

43. Germano S, O’Driscoll L. Breast cancer: understanding sensitivity and resistance to chemotherapy and targeted therapies to aid in personalised medicine. Curr Cancer Drug Targets. 2009;9(3):398-418.

44. Siegel R, DeSantis C, Virgo K, et al. Cancer treatment and survivorship statistics, 2012. CA Cancer J Clin. 2012;62(4):220-241.

45. Lee MC, Gray J, Han HS, Plosker S. Fertility and reproductive considerations in premenopausal patients with breast cancer. Cancer Control. 2010;17(3):162-172.

46. Howard-Anderson J, Ganz PA, Bower JE, Stanton AL. Quality of life, fertility concerns, and behavioral health outcomes in younger breast cancer survivors: a systematic review. J Natl Cancer Inst. 2012;104(5): 386-405.

47. Meneses K, Azuero A, Hassey L, McNees P, Pisu M. Does economic burden influence quality of life in breast cancer survivors? Gynecol Oncol. 2012;124(3):437-443.

48. Ashing-Giwa KT, Lim JW. Exploring the association between functional strain and emotional well-being among a population-based sample of breast cancer survivors. Psychooncology. 2010;19(2): $150-159$.

49. Heidari Gorji MA, Bouzar Z, Haghshenas M, Kasaeeyan AA, Sadeghi MR, Ardebil MD. Quality of life and depression in caregivers of patients with breast cancer. BMC Res Notes. 2012;5:310.

50. Brem S, Kumar NB. Management of treatment-related symptoms in patients with breast cancer. Clin J Oncol Nurs. 2011;15(1):63-71.
51. Schmitz KH, Speck RM, Rye SA, DiSipio T, Hayes SC. Prevalence of breast cancer treatment sequelae over 6 years of follow-up: the Pulling Through Study. Cancer. 2012;118(Suppl 8):2217-2225.

52. Buijs C, de Vries EG, Mourits MJ, Willemse PH. The influence of endocrine treatments for breast cancer on health-related quality of life. Cancer Treat Rev. 2008;34(7):640-655.

53. Burris HA, Lebrun F, Rugo HS, et al. Health-related quality of life of patients with advanced breast cancer treated with everolimus plus exemestane versus placebo plus exemestane in the phase 3 , randomized, controlled, BOLERO-2 trial. Cancer. 2013;119(10):1908-1915.

54. EORTC Quality of Life Group. EORTC QLQ-C30 (version 3). Brussels: EORTC Quality of Life Group; 1995. Available from: http://groups. eortc.be/qol/sites/default/files/img/slider/specimen_qlq-c30_english. pdf. Assessed December 18, 2013.

55. EORTC QLQ-BR23 [webpage on the Internet]. Brussels: EORTC Quality of Life Group; 1994. Available from: http://groups.eortc. be/qol/sites/default/files/img/specimen_br-23_english.doc. Assessed December 18, 2013

56. Barron JJ, Quimbo R, Nikam PT, Amonkar MM. Assessing the economic burden of breast cancer in a US managed care population. Breast Cancer Res Treat. 2008;109(2):367-377.

57. Fu AZ, Jhaveri M. Healthcare cost attributable to recently-diagnosed breast cancer in a privately-insured population in the United States. J Med Econ. 2012;15(4):688-694.

58. Sorensen SV, Goh JW, Pan F, et al. Incidence-based cost-of-illness model for metastatic breast cancer in the United States. Int J Technol Assess Health Care. 2012;28(1):12-21.

59. Schwartzberg L, Streeter SB, Hussain N, Johnsrud M. Abandoning oral oncolytic prescriptions at the pharmacy: patient and health plan factors influencing adherence. Poster presented at: Annual Meeting of the American Society of Clinical Oncology; June 3-7, 2011; Chicago, IL, USA.

60. National Institute for Health and Care Excellence. Everolimus in Combination with Exemestane for Treating Advanced HER2-Negative Hormone-Receptor-Positive Breast Cancer After Endocrine Therapy. NICE Technology Appraisal Guidance 295. London: National Institute for Health and Care Excellence; 2013. Available from: http://www.nice. org.uk/nicemedia/live/14265/65061/65061.pdf. Accessed December 18, 2013.

61. Chlebowski RT, Geller ML. Adherence to endocrine therapy for breast cancer. Oncology. 2006;71(1-2):1-9.

62. Sedjo RL, Devine S. Predictors of non-adherence to aromatase inhibitors among commercially insured women with breast cancer. Breast Cancer Res Treat. 2011;125(1):191-200.

63. Wu J, Lu ZK. Hormone therapy adherence and costs in women with breast cancer. Am J Pharm Benefits. 2013;5(2):65-70.

64. Simons WR, Jones D, Buzdar A. Cost-effectiveness of anastrozole versus tamoxifen as first-line therapy for postmenopausal women with advanced breast cancer. Clin Ther. 2003;25(11):2972-2987.

65. Dunn C, Keam SJ. Letrozole: a pharmacoeconomic review of its use in postmenopausal women with breast cancer. Pharmacoeconomics. 2006;24(5):495-517.

66. Cameron DA, Camidge DR, Oyee J, Hirsch M. Economic evaluation of fulvestrant as an extra step in the treatment sequence for ER-positive advanced breast cancer. Br J Cancer. 2008;99(12):1984-1990.

67. Zeichner SB, Raja Avancha KKV, Lopes G, Gluck S, Montero AJ. Cost-effectiveness of everolimus plus exemestane in post-menopausal hormone receptor positive metastatic breast cancer [American Society of Clinical Oncology Annual Meeting abstract]. J Clin Oncol. 2013;31(Suppl 15):6548.

68. Xie J, Diener M, De G, Yang H, Wu EQ, Namjoshi M. Budget impact analysis of everolimus for the treatment of hormone receptor positive, human epidermal growth factor receptor-2 negative (HER2-) advanced breast cancer in the United States. J Med Econ. 2013;16(2):278-288.

69. Garreau JR, Delamelena T, Walts D, Karamlou K, Johnson N. Side effects of aromatase inhibitors versus tamoxifen: the patients' perspective. Am J Surg. 2006;192(4):496-498. 


\section{Publish your work in this journal}

ClinicoEconomics \& Outcomes Research is an international, peerreviewed open-access journal focusing on Health Technology Assessment, Pharmacoeconomics and Outcomes Research in the areas of diagnosis, medical devices, and clinical, surgical and pharmacological intervention. The economic impact of health policy and health systems organization also constitute important areas of coverage. The manuscript management system is completely online and includes a very quick and fair peer-review system, which is all easy to use. Visit http://www.dovepress.com/testimonials.php to read real quotes from published authors.

Submit your manuscript here: http://www.dovepress.com/clinicoeconomics-and-outcomes-research-journal 